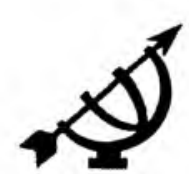

\title{
Opvoeding vir die vroeg-21 ste eeu: 'n Christelik-opvoedkundige perspektief
}

\author{
J.L. van der Walt \\ Fakulteit Opvoedkunde \\ Potchefstroomse Universiteit vir $\mathrm{CHO}$ \\ POTCHEFSTROOM \\ E-pos: dopfjcl@puknet.puk.ac.za \\ Abstract
}

Education in the early 21 st century: A Christian-educational perspective

The transition from one century to another calls educators and educationists to scrutinize trends from the past and the present, and to realistically project them into the future. They need to do this because of the future-directedness of education and educational science: people have to be educated in order to be empowered for meaningful future existence. The research underlying this article was inspired by the transition from the 1900 s to the 2000s, as well as by President Mbeki's injunction that South African educators should be prepared to face the next century. With reference to the "Tirisano" project, a probable religious-cultural-social scenario for the first decades of the next century is described and evaluated from a Biblical-educational point of view. The discussion is concluded by expressions of concern about the secular and humanistic nature of both the "Tirisano" programme and the broader global trends with which educators will have to grapple in the next few decades.

\section{Oriënterende agtergrond}

Die oorgang van die een dekade na die volgende, of die een eeu na die volgende, noop 'n mens om 'n oomblik tot stilstand te kom en poolshoogte te neem. Dit dwing 'n mens om ook, vir sover dit vir die mens met sy beperkte vermoëns moontlik is, vorentoe te kyk na die uitdagings en die tendense wat om die draai wag. Dit was ook nie anders met die oorgang vanaf die negentigerjare na 2000 nie. Dit het Thabo Mbeki, president van die Republiek van Suid-Afrika, daartoe gebring om na aanleiding van die onderwyssituasie in die land die vraag te stel: "Is our education system on the road to the 21st century?" (Asmal, 1999, 2000, 2000b). 
Dit skyn of daar nie in reaksie op hierdie belangrike vraag 'n deeglike bestekopname gedoen is van wat opvoeders en opvoedkundiges in die 21 ste eeu te wagte kan wees, en hoe hulle daarop behoort te reageer nie. Desondanks het die ministerie van onderwys op hierdie vraag van president Mbeki gereageer deur agtereenvolgens twee prioriteitsprogramme vir die onderwys van die vroeg-21ste eeu aan te kondig. In Julie 1999 is die "Batho Tele"-program ("Call to action") aangekondig, bestaande uit nege prioriteite vir die onderwys in die afsienbare jare. Hierdie program is in Januarie 2000 geamendeer met die afkondiging van die "Tirisano"-program ("Ons werk saam"), wat vyf prioriteite vir die onderwys uitstippel (Asmal, 1999, 2000, 2000b). Die vyf prioriteite is: die verbreding van kennis oor HIVNIGS, die verbetering van die effektiwiteit van skole, die bevordering van geletterdheid, die verbetering van die verdere en hoër onderwys, asook die verbetering van die organisatoriese effektiwiteit van die nasionale en provinsiale onderwysdepartemente (Anon., 2000).

Elkeen wat op hoogte is met die onderwyssituasie in Suid-Afrika en Afrika in die algemeen, sal onmiddellik toegee dat hierdie prioriteite gepas is met die oog op die verbetering en opgradering van die onderwys in Suid-Afrika.

Die doel met hierdie bespreking is om ' $n$ scenario vir die afsienbare toekoms te skets waarmee opvoeders en opvoedkundiges, en veral Christen-opvoeders en -opvoedkundiges, in hulle onderskeie praktyke rekening sal moet hou. Dit sal uit die scenarioskets hieronder blyk dat die vermelde "Tirisano"-prioriteite vir die onderwystoekoms in Suid-Afrika te eng en plaaslik van aard is om die uitdagings van die toekoms toereikend die hoof te kan bied. Hierdie gevolgtrekking kan 'n mens maak ten spyte van die feit dat die "Tirisano"-program uitdruklik in die konteks van die Afrika-renaissance-program van president Mbeki geplaas is. Mbeki (1999a, 1999b) sowel as Mseleku (2000), die twee dryfkragte agter die Afrika-renaissance- en die "Tirisano"-programme, stel dit met nadruk dat aan die een kant die Afrika-erfenis en -situasie in ag geneem moet word, maar dat aan die ander kant nie vergeet mag word dat Afrika in die konteks van 'n kleiner wordende globale werklikheid gesitueer is nie. 'n Mens kan egter aandui dat aan laasgenoemde konteks nie die nodige aandag gegee is in die formulering van die vyf prioriteite van die "Tirisano"-program nie.

'n Poging om 'n toekomsscenario vir die onderwys te skets is egter nie slegs belangrik omdat die president van die land daarna vra nie, en ook nie omdat onderwyshervormingsprogramme aangekondig is om vir daardie toekoms gereed te maak nie. Christen-opvoeders en -opvoedkundiges stel in die toekoms belang omdat opvoeding en onderwys toekomsgerigte handelinge is; die opvoedeling / leerder moet in die hede 
gereed gemaak word vir die uitdagings van die toekoms wanneer hy of sy 'n volwasse mens geword het. Opvoeders en opvoedkundiges moet dus 'n opvatting hê van wat redelikerwys in die afsienbare toekoms gaan gebeur ten einde doelgerig en doeltreffend te kan opvoed, onderwys te gee en die wetenskap van die opvoedkunde te beoefen (Sine, 1997:25, 38; vgl. Engelbrecht \& Nieuwenhuis, 1988:179).

Vir Christen-opvoeders en -opvoedkundiges wat, net soos enige ander mens, nie in die toekoms kan inkyk nie, is dit belangrik om aan die perspektief vas te hou dat sekere huidige tendense in die toekoms sal voortduur, en dat die toekoms nie skielik rewolusionêr op sy kop gedraai sal word nie. Die toekoms is per slot van rekening in die hande van God, en Hy laat dit histories-ordelik in die tyd ontplooi. God het die mens toegerus met die redelike vermoë om, deur die ontleding van tendenslyne uit die verlede en die hede, op beperkte wyse in die toekoms in te kyk. Die mens is deur God in die tyd en in die geskiedenis geplaas, en weens hierdie feit moet hy of sy deelneem aan die voortgang van die geskiedenis in die diens en tot eer van God. As "toekomskyker" is die mens dus tegelyk ook "toekomsskepper"; hy neem deel aan en vorm die toekoms wat hy probeer sien, verstaan en skets.

Die mens se dade en optredes as "toekomskyker" en "toekomsmaker" lê in die spanning tussen tradisie (verlede) en voortgang (hede en toekoms), en nie een van hierdie pole mag oorbeklemtoon word nie. Nie die pole is deurslaggewend nie - wel die proses van sin- of betekenisontplooiing in Jesus Christus in die tyd en geskiedenis tussen die pole (Rushdoony, 1969:67-90). Die ontplooiing van die geskiedenis, meen Dooyeweerd (1979:66 e.v), veronderstel kulturele mag, en dit is onderworpe aan die norm van historiese kontinuïteit binne die vermelde spanning tussen tradisie en voortgang. Dit is juis hierdie norm wat die "beperkte vorentoe-kyk in die toekoms" moontlik maak.

Die skets van toekomsscenario's is dus nie profesieë of voorspellings nie; ook nie raaiwerk nie, maar is die beskrywing van tendense in die spanningsveld tussen tradisie en progressie (die ontplooiende hede en toekoms) wat reeds eietyds raakgesien kan word, en waarvan 'n vorm van histories-logies-liniêre ontplooiing in die toekoms verwag kan word.

- As 'n eerste stap probeer 'n mens die aantal toekomsmoontlikhede vir die stelsel waarmee jy te doen het, beperk. 'n Mens doen dit deur die reëls van die spel (byvoorbeeld die ekonomie of die onderwys) wat die moontlikhede bepaal, te verstaan, en daarmee word tegelyk die omvang van die moontlikhede beperk (onderwystoestande kan dus voorsien word omdat die onderwys volgens bepaalde spelreëls geskied). 
- Die tweede stap is die bepaling van sleutelonsekerhede wat die stelsel onder ontleding na die een of die ander kant toe kan laat ontwikkel.

- Die derde stap is om die "reëls van die spel" en die sleutelonsekerhede te kombineer.

Hierdie oefening verskaf dan aan 'n mens "toekomste" wat binne redelike perke lê (Sunter, 1996:12-13). Dit is vir opvoeders en opvoedkundiges noodsaaklik om van tyd tot tyd hierdie oefening te doen: eers as 'n mens 'n idee het hoe die toekoms daar gaan uitsien, kan besin word oor wat die aard van die onderwys en opvoeding in daardie soort omstandighede sal moet wees (Goudzwaard, 1997:40).

In die volgende afdeling kry ons 'n oorsig oor tendense vir die toekoms wat reeds in die tagtigerjare deur opvoedkundiges raakgesien is, en waarvan 'n groot gedeelte vandag nog relevant is en waarskynlik ook vir die eerste dekades van die volgende eeu relevant sal bly, onder andere weens die stadig veranderende aard van die onderwys. In afdeling 3 word 'n stap verder gegaan. Aan die hand van literatuur en op sterkte van logiese deurdenking van verskillende moontlikhede (reëls van die spel, sleutelonsekerhede), word ' $n$ aantal toekomstendense wat vir opvoeders en opvoedkundiges van belang kan wees, beskryf. Al hierdie tendense saam vorm 'n moontlike scenario vir die toekoms. Die sleutelwoord hier is "moontlike", aangesien die omstandighede waarin mense aan die einde van die 20 ste eeu en aan die begin van die 21 ste eeu leef, te midde van al die stabiliteit wat God se hand aan die toekoms verleen, taamlik onseker en vinnig wisselend is. Om hierdie rede moet 'n mens dus nie probeer om sommer verder as vyf jaar vorentoe te kyk nie Om ' $n$ voorbeeld te noem: die kurrikulumhervormingsprogram bekend as Kurrikulum 2005 wat in 1997 aangekondig is (Dept. van Onderwys, 1997; SAOU, 2000) en wat teen 2005 geïmplementeer moes gewees het, is in die loop van 2000 vervang met Kurrikulum 21.

\section{Terugskouing: opvoeding in die 21 ste eeu - twee sieninge uit die tagtigerjare}

Enigiemand wat enigsins aktief in die onderwys was gedurende die afgelope ongeveer twee dekades sal dadelik toegee dat die twee beskrywings van toekomstendense aan die einde van die 20ste eeu deur Wragg (1984) en Engelbrecht en Nieuwenhuis (1988) taamlik in die kol was. Om die waarheid te sê, baie min daarvan is nie relevant vir die laaste dekade of twee van die 20ste eeu en die eerste dekade of twee van die 21ste eeu nie. Ruimte om die "akkuraatheid" van die scenario's te bespreek, ontbreek egter. 'n Mens kan egter volstaan met die op- 
merking dat die volgende aspekte van die scenario's nog van besondere betekenis is aan die begin van die 21 ste eeu:

- die onderwysomgewing word gekenmerk deur verandering, onsekerheid, onstabiliteit en dinamika, en tog is daar 'n onvermydelike inherente traagheid in onderwysverwikkelinge te bespeur;

- die verandering is meestal van sosiaal-maatskaplike, demografiese en tegnologiese aard, byvoorbeeld die vergrysing (veroudering) van sommige gemeenskappe, en die vergroening (oorwig jongmense) van ander;

- daar is toenemde werkloosheid en dus meer vrye tyd;

- die kwalifikasiespiraal neig al hoër;

- die toepassing van kennis is belangriker as die verkryging of bemeestering van kennis;

- elektroniese media skep voortdurend nuwe metodes om te leer en kennis te bemeester;

- groter artikulasie tussen onderwys- en opleidingsmodi vind plaas;

- daar is 'n groter premie op ouersamewerking en gemeenskapsdeelname aan die onderwys:

- kurrikula raak al oper; tradisionele vakke verdwyn (vgl. Kurrikulum 2005/21); kruiskurrikulêre en sosiale vaardighede raak belangriker (leerareas);

- onderwys raak onbekostigbaar, en daar is 'n neiging tot privatisering;

- leerdergetalle neem in onwikkelende lande toe; daar is 'n strewe na die uitwissing van ongeletterdheid en na universele onderwys (vgl. een van die prioriteite in die "Tirisano"-projek);

- toenemend heterogene gemeenskappe vereis 'n groter toepassing van multikulturele onderwysbeginsels

Voorgaande tendense uit die 20ste eeu geld ook in 'n hoë mate vir minstens die eerste dekades van die volgende eeu. Op grond van wat 'n mens nou al kan waarneem, sal minstens die eerste jare van die 21ste eeu deur hierdie tendense gekenmerk word. Hulle mag egter ietwat anders genuanseerd aan bod kom. Die res van hierdie oorsig word aan sulke moontlike nuanseringe gewy.

\section{Tendense van die derde millennium}

Die volgende tendenslyne uit die laaste dekade of twee van die twintigste eeu en wat oorspoel in die een-en-twintigste eeu is vir die opvoed- 
Opvoeding vir die vroeg-21ste eeu 'n Christelik-opvoedkundige perspektief

kundige van belang. Daar sal in die opvoedings- en onderwysarbeid van die komende aantal jare erns gemaak moet word met die vorming van opvoedelinge of leerders ten einde hulle toe te rus om hierdie tendense of neigings die hoof te bied. Veral Christen-opvoeders en -onderwysers sal groot erns met hierdie taak moet maak aangesien heelwat van hierdie tendense nie versoenbaar met die beginsel- en normstruktuur voortvloeiend uit 'n Bybelsgefundeerde lewens- en wêreldbeskouing is nie. Hierdie vormingstaak sal in sommige gevalle duidelike afkeer en verwerping van die hedendaagse tendense behels, maar in ander sal dit daarop neerkom dat die jonger geslag gehelp moet word om in hierdie wêreld te wees maar nie deel daarvan nie (Rom. 12:2; I Kor. 7:29-31; Kol. 3:2,5; 2 Tim. 2:22; Jak. 4:4; I Joh. 2:15-17).

\subsection{Kulturele ongemak}

Daar is deesdae 'n gevoel van kulturele ongemak, meen Walsh (1997:8), maar dit is nie altyd seker wat presies dit veroorsaak nie. Dit is moontlik dat mense 'n gevoel van postmoderne ontwrigting en ongemaklikheid ervaar. Die gevoel van ongemak en onrus gaan soms gepaard met gevoelens van verraad en ontnugtering, veral onder jongmense. Hierdie gevoelens het hulle ontstaan uit die besef dat beloftes wat aan hulle gemaak is dat hulle eendag op dieselfde lewenstandaard as hulle ouers sal kan lewe, nie nagekom (kan) word nie. Hierdie gevoelens lei soms daartoe dat sulke jongmense vertroue in die toekoms verloor (Walsh, 1997:8-9). Die verdere tendense tot "dispersie" en "erosie" (waaroor hieronder gehandel word) versterk hierdie gevoelens deur twyfel en vrees oor die toekoms te laat posvat (Goudzwaard, 1997:43).

Hierdie tendense is ook sigbaar in Afrika, meen Van der Walt (1997:123 e.v.). Na sy oordeel veroorsaak dit in Afrika 'n krisis van ongekende omvang en diepte. Die probleem is groter as elders omdat die meeste Afrikane om verskillende redes, waarop nie hier ingegaan kan word nie, blind is vir die krisis. Hy meen dat ook Suid-Afrika toenemend in die krisis vasgevang sal raak namate dit aanvaar word as deel van Afrika. Die uitsigloosheid vir die toekoms word onder meer veroorsaak deur armoede met die gepaardgaande verskynsels van hongersnood, siekte, onreg, politieke onstabiliteit en verontmensliking (p. 124)

Solank die mens homself outonoom waan, dit wil sê as sy of haar eie wetgewer, en nie meer in afhanklikheid van sy Skepper wil leef en werk nie, kan hy of sy nie genormeerd rigting en vorm gee aan die kultuurmandaat (Gen. 1:26-30) nie. Omdat kultuurbeoefening, en die lewe in die algemeen, sedert die sondeval nie religieus Godgerig is nie, maar gebroke in die afval gerig is, lei dit vir die God-lose mens onvermydelik tot hierdie kulturele ongemak, wat so kenmerkend is van 
die sekulêre samelewing. Die ongemak raak gebore uit 'n gevoel van sinverlies; die mens as beeld van God (Gen. 1:27) ontdek die sin van sy of haar bestaan in toegewyde diens aan God (I Joh. 5:2-3; 2 Joh. 6) en liefde vir die medemens (Joh. 13:34-35). As hierdie sinperspektief ontbreek en sinverlies intree, is die gevolg eksistensiële ongemak. Die antwoord vir die mens van die 21 ste eeu is om terug te keer na God, om sy hart religieus volledig op God gerig te hou, en om in alles wat hy doen God te dien en te eer (Matt. 22:37-40).

\subsection{Globalisering en markgerigte kolonisasie}

Daar is magte wat die wêreld in die rigting van 'n welvarender toekoms stoot deur globalisering, deregulering en bevryding te predik. Hierdie magte, saam met die groei in tegnologie, interaksie en interafhanklikheid dwing die wêreld om 'n universele ekonomiese model te vorm. Ook vir die toekomstige welvaart van Suid-Afrika is ekonomiese groei die voorwaarde; dit is die lym wat die land aanmekaar gaan hou, meen Sunter (1996:102). Soos in alle ander "wenlande" sal mense toenemend nie omgee wie die politieke leiers is nie, solank hulle net kan besig wees om vir hulleself en vir hulle eie mense welvaart te skep. Selfs die skepping van sosiale welvaartsprogramme is afhanklik van ekonomiese groei.

Om al hierdie redes is daar 'n opvallende tendens onder nasionale ekonomieë om op te gaan in een globale ekonomie (Sine, 1997:26). Hierdie tendens het tot gevolg dat die hele hedendaagse leefwêreld toenemend deur markgerigte kragte "gekolonialiseer" word (Tennekes, 1992: 54), en selfs die onderwys moet allerlei ekonomiese prioriteite dien (Goudzwaard, 1997:40). Die onderwys moet byvoorbeeld 'n nuwe houding tot arbeid tuisbring: om te werk is soos om in 'n toneelstuk te speel. Sodra die stuk klaargespeel is en daar nie meer toeskouers is wat betaal om dit te sien nie, is dit tyd vir die toneelspelers om aan te skuif na 'n nuwe toneelstuk. Die sleutelwoord is dus werkgeskiktheid en nie meer indiensneming nie; die vermoë om verskeie rolle te speel kan jou jou volgende werk besorg (Sunter, 1996:104). Die onderwys moet verder ook sorg dat mense entrepreneurs word; hulle moet vir hulleself werk skep eerder as om vir base te gaan werk (Sunter, 1996:107).

Soos aangetoon, sal die ekonomieë van die toekoms toenemend gekenmerk word deur die tendense van "dispersie" en "erosie". "Erosie" is reeds 'n bekende verskynsel: die uitbuiting van die omgewing en die verwaarlosing van die medemens. Die toenemende markgerigte kolonisasie, die wetenskap, die tegnologie en die ekonomie is reeds besig om swaar laste op die omgewing te lê, en die verswakking van die omgewing gaan lei tot ' $n$ daling in mense se bestaanskwaliteit. Selfs in 
Opvoeding vir die vroeg-21ste eeu: 'n Christelik-opvoedkundige perspektief

ryk gemeenskappe word die versorging van bejaardes, gestremdes en ander hulpbehoewendes agterweë gelaat. Volgens Goudzwaard (1997: 41-43) is dit een van die paradokse in gemeenskappe wat besig is om welvarend te raak (vgl. 3.9 hieronder vir 'n bespreking van "dispersie").

Hierdie tendense geld ook in Afrika, met die verskil dat byna geen Afrikaland 'n gesonde ekonomie het nie. Geweldige prysstygings en inflasie lei tot groot ellende in baie van hierdie lande. Die probleem word vererger deur werkloosheid, politieke korrupsie, ongebreidelde bevolkingsgroei en die devaluasie van geld teenoor buitelandse geldeenhede. Afrikane is in baie gevalle nie eens meer in staat om die lewenspeil van die sestigerjare te handhaaf nie. Kortom: armoede is besig om sy episentrum in Afrika te vind, en dit plaas ernstige druk op die voorsiening van dienste soos die onderwys en gesondheid. Ongeveer $70 \%$ van alle Afrikane leef van die hand na die mond (bestaansekonomie), en hierdie toestande gaan meermale gepaard met korrupte politieke praktyke (Van der Walt, 1997:124 e.v.).

Op sigself is globalisering en die uitbreiding van die ekonomieë van lande nie verkeerd nie, en selfs onvermydelik. Globalisering geskied weens die mens se Godgegewe vindingrykheid om die wêreld tegnologies te beheers, en is ' $n$ uitvloeisel van die mens se nakoming van die kultuurmandaat. Die probleem is egter dat globalisering en ekonomiese groei op sigself as die doel van die mens se bestaan gesien word, en God nie meer in die sentrum van hierdie kultuurarbeid gesien word nie en dit 'n moderne idool of afgod word. Wanneer globalisering en ekonomiese uitbreiding ongenormeerd deur die tweeledige liefdesboodskap van die Skrif voortgaan (Matt. 22:37-40), vind allerlei skeeftrekkinge plaas. Markkolonisasie, tegnokrasie, oordrewe strewes na ekonomiese groei, geweldige rykdom aan die een kant teenoor uiterse armoede aan die ander kant, is voorbeelde van sulke skeeftrekkinge. Die oplossing vir die mens van die 21 ste eeu is om alle vorme van kultuurbeoefening soos die ontwikkeling van tegnologie, informasieverspreiding en die ontwikkeling van ekonomieë volledig aan die diens van God toe te $w y$, en om die medemens in die proses nie aan sy of haar lot oor te laat nie. Die sleutel is ewewigtige ontwikkeling, met God en sy koninkryk in die sentrum van belangstelling.

\subsection{Strewe om deel te vorm van die middelklas}

Sedert die einde van die "koue oorlog" is daar in baie gemeenskappe 'n strewe om die ekonomie so te laat groei dat dié gemeenskappe deel kan word van 'n relatief welvarende middelklas (vgl. 3.9 vir 'n kort oorsig van die gelyktydige erosie van die middelklas). Daar is egter soveel plaaslike oorloë in die wêreld dat dit die groei van die wêreldekonomie strem 
asook die ontstaan van 'n meer gegoede middelklas. Hierdie strewe om die Westerse lewenstyl te volg en tot die middelklas te kan behoort, kan op die duur ook bydra tot globale verwarming en uitputting van die omgewing (Sine, 1997:27-28).

Op sigself is dit ook nie verkeerd om daarna te streef om jouself en jou omstandighede te ontwikkel en verbeter nie. As 'n mens uitgaan van die gedagte dat God die Gewer van alle goeie dinge is (Ps. 21:2 e.v.; 34:1011, 84:11-13), en dat Hy oorvloediglik aan almal kan en wil gee (Ps. 136:25; 145:15-16), behoort dit in beginsel moontlik te wees vir almal om opgehef te word tot 'n beter vlak van bestaan. Weens die sondige afvalligheid en liefdeloosheid van die hedendaagse mens word die gedagte van God se goedheid en oorvloedigheid misgekyk, en streef elkeen net om die beste vir homself en vir diegene wat aan hom behoort, te verseker. Die hedendaagse samelewing het om hierdie rede uiters selfsugtig, mededingend en liefdeloos geword. Die oplossing vir hierdie negatiewe tendens van die toekoms is om steeds vas te hou aan die gedagte van God se oorvloedige gawes en dat almal "bemagtig"' (in staat gestel, onder andere deur opvoeding en onderwys) moet word om daarin te kan deel (Sag. 10:1; Matt. 6:11). Om dit te bereik sal selfgesentreerde selfsugtigheid teengewerk moet word

\subsection{Ongebreidelde bevolkingstoenames}

Na verwagting sal die 5.8 miljard mense op aarde van 1994 aangroei tot meer as 11 miljard teen 2050. Van eersgenoemde syfer leef ongeveer een miljard reeds in uiterste armoede. Aan die een kant word die wêreld dus kleiner, die hulpbronne al beperkter, en aan die ander kant word die wêreld al hoe voller en neem die druk op hulpbronne toe (Sine, 1997: 29)

As God die opdrag gee dat die mense moet vermeerder en die aarde moet bewoon en bewerk (Gen. 1:28), is die bedoeling uiteraard dat dit in verantwoordelikheid moet geskied. Die feit dat bevolkingstoenames in die mins ontwikkelde gemeenskappe geskied, is 'n aanduiding dat hierdie sin vir verantwoordelikheid nog nie daar tuisgekom het nie. Dit is die dure plig van Christen-opvoeders om die mense wat in spirale van bevolkingsontploffing-armoede vasgevang geraak het, deur opvoeding te help om hulle eie omstandighede te verstaan en te kan beheer. Dit is ' $n$ taak van onbeskryflike omvang, en daarom is dit geen wonder dat mense daarvoor terugdeins nie. Om bloot geld in hierdie arm gemeenskappe in te pomp en sodoende hulle skuldlas te vergroot is geen oplossing nie Goeie Skrifgefundeerde opvoeding kan wel aan dié mense die kennis en die inligting gee om hulle toekomstige situasie te verbeter. 


\section{5 'n Wêreld toenemend beheers deur die wetenskap en die tegnologie}

Die hedendaagse mens se beeld van die werklikheid word veelal deur die wetenskap en die tegnologie bepaal en beskryf (De Knijff, 1992). Ongelukkig is die rasionaliteit onderliggend aan hierdie wetenskap en tegnologie eng van aard: tydens die Verligting het rasionaliteit nog te doen gehad met moraal en religie, maar deesdae het dit byna uitsluitlik net met objektiewe feite en koel doeltreffendheid en doelmatigheid te doen. Hierdie verengde basis het ook tot gevolg dat daar 'n skeiding tussen feite en waardes plaasgevind het (Tennekes, 1992:56; Baer, 1987:14 e.v.). Die hedendaagse siening van die funksie van die wetenskap en die tegnologie het tot gevolg dat dit veral hierdie dinge is wat die mens in staat stel om doeltreffend en doelmatig te kan optree. Hierdie tendens gaan gepaard met ' $n$ verlies aan besef van samehang: die samehang tussen lewensbeskouing en wetenskap, tussen werklikheid en wetenskap, tussen wetenskap en samelewing word nie meer raakgesien nie - ten spyte van die duidelike behoefte aan insig in hierdie samehange (Dekker, 1992:68).

Die wetenskap en die tegnologie is middele deur God aan die mens gegee om die skepping mee te ken en te beheers, en is derhalwe onontbeerlik in die uitvoering van die kultuurmandaat. 'n Ewewigtige, mens- en omgewingsvriendelike siening van die wetenskap en die tegnologie is egter nodig om te verseker dat uitbuiting, onderdrukking en manipulasie van die skepping en die medemens nie plaasvind nie. Die gevaartekens flikker as skrywers begin praat van die erosie en die uitbuiting van die omgewing, en van die feit dat die mens deur die wetenskap en die tegnologie beheers word. Die mens is per slot van rekening die kroon van die skepping, God se verteenwoordiger op aarde (Gen. 1:26; Ps. 8: 5-6; Heb. 2:7-8). As hierdie ereposisie van die mens nie meer raakgesien en erken word nie, dan het dit vir die mens hoog tyd geword om terug te keer na 'n siening van die wetenskap en die tegnologie as blote instrumente in die hande van die mens om sy Goddelike opdragte na te kom. Die mens moet te alle tye die wetenskap en die tegnologie tot eer van God en tot voordeel van die medemens beheer(s), en nie andersom nie. Indien die omgekeerde gebeur, vind ontmensliking, vervreemding en liefdeloosheid teenoor God en die naaste 'n vastrapplek.

\subsection{Die wêreldwye elektroniese netwerk en die globalisering van kultuur}

Die hedendaagse mens bevind hom in 'n elektroniese senustelsel van satellietskottels, faksmasjiene, selfone, elektroniese pos, rekenaars, internet, televisie, CD-spelers en ander verbindinge. Die teenwoordigheid 
van hierdie toerusting bring ' $n$ vryer vloei van inligting mee, maar veroorsaak ook ' $n$ vorm van kulturele gelykmaking (Amerikanisering?), en veroorsaak ' $n$ inkopiesentrum- of ' $n$ karnavalbenadering tot die kultuur. Die vermaaklikheidswêreld (vgl. speletjie-arkades) het al groot bydraes gemaak tot die globalisering van kultuur, en tot die vorming van nuwe waardestelsels onder jongmense (Sine, 1997:30). Een van die paradokse van die huidige tyd en van die afsienbare toekoms is dat minderbevoorregte mense van hierdie nuwe ontwikkelinge verstoke is (Sine, 1997:35). Diegene wat egter wel toegang daartoe het, neig om verstrengel te raak in ' $n$ virtuele wêreld, en om vervreemd te raak van die werklike wêreld en sy inwoners. Op hierdie manier vind verslawing aan virtuele seks en geweld plaas (Sine, 1997:36). Al hierdie ekstreme ervarings lei tot ' $n$ gevoel van afstomping en verveeldheid onder jongmense, omdat daar niks meer is wat nie reeds beproef is nie. Niks is meer nuut nie; mediaversadiging het ingetree; jongmense droom nie meer oor die toekoms nie (Walsh, 1997:10-12).

Indien kultuurbeoefening ewewigtig geskied, kan die mens met vreugde daarvan geniet, maar indien die ewewig verlore gaan, dan tree allerlei uitwasse in. Dit sal die mens van die 21 ste eeu dus loon om 'n versigtige ontleding te maak van wat God werklik in die kultuurmandaat (Gen. 1:2830) genormeer het, en om hierdie norme onverwyld toe te pas.

\subsection{Groter sosiale mobiliteit en migrasie lei tot groter heterogeniteit}

Weens die kleiner wordende wêreld en die groter beweeglikheid van mense is daar toenemende migrasie, nie slegs in ruimtelike sin nie maar ook in sosio-ekonomiese sin. Al hierdie bewegings lei tot groter heterogeniteit in gemeenskappe, gepaardgaande met multikulturaliteit en veeltaligheid. Groter getalle ouers kom onder die besef van die belangrikheid om hulle kinders voor te berei vir 'n toekomstige lewe in sulke heterogene gemeenskappe (Sleeter \& Grant, 1994:243 e.v.).

Die groter sosiale mobiliteit en die toenemende heterogeniteit van toekomstige samelewings is ' $n$ onontkombare feit, ' $n$ onvermydelike gevolg van die al kleiner wordende wêreld. Dit is derhalwe vir die Christen in die algemeen, en die opvoeder in die besonder, van die grootste belang om die leerders van die toekoms toe te rus om in hierdie soort omgewing te leef, te werk en die self te kan handhaaf, terwyl daar ook ruimte vir die ander gegun moet word om in hierdie klein wêreld ' $n$ sinvolle bestaan te voer. Diversiteit-in-eenheid is per slot van rekening een van die Godgegewe kenmerke van die werklikheid waarin die mens hom of haar bevind. 


\subsection{Vergrysing van die bevolkings in meer welvarende lande}

Die meeste van die "baby boomers" (diegene gebore tussen 1942 en 1963) sal binne die afsienbare tyd aftree. In die voormalige geallieerde lande van die Tweede Wêreldoorlog is daar ongeveer 77 miljoen van hulle. Dit is duidelik dat hierdie lande aan die verskynsel van "vergrysing" begin ly en dat, weens beter mediese versorging en 'n langer lewensverwagting, hierdie tendens in intensiteit gaan toeneem. Dit sal tot die probleem lei dat al minder mense al meer mense sal moet onderhou. Dit sal lei tot allerlei vorme van belasting, dog tegelyk ook tot nuwe vorme van arbeid, veral in die geriatriese rigtings (Sine, 1997:31-32).

Ook hierdie is ' $n$ onontkombare omstandigheid waarmee in die toekoms saamgeleef moet word. Die jongmense van die afsienbare toekoms sal opgelei moet word om allerlei vorme van produktiewe werk te kan doen sodat hulle kan bydra tot die versorging van al die ander mense in hulle gemeenskappe, en om ook vir hulle eie oudag te kan sorg. Hulle sal ook gelei en toegerus moet word om beroepe in die geriatiese rigtings te kies, en om produktiwiteit in daardie rigtings te bewerkstellig.

\section{9 'n Toenemende gaping tussen arm en ryk}

Weens die verskynsel van "dispersie" gaan daar 'n groeiende gaping tussen arm en ryk intree. Dispersie gaan gepaard met die globalisering van die ekonomie. In die nuwe globale ekonomie gaan daar ekonomiese pole ontstaan, wat sommige van die "deeltjies" gaan aantrek, en andere gaan afstoot - na die periferie toe of selfs heeltemal van die toneel af. Almal sal byvoorbeeld nie in die ekonomiese voordele van ' $n$ bepaalde pool kan deel nie; die vrye vloei van kapitaal sal daarvoor sorg dat sommige in die rykdom kan deel en ander nie, en dat die kloof tussen ryk en arm gevolglik sal verdiep. Allerlei vorme van dispersie sal selfs binnein ryk lande plaasvind, wat aanleiding sal gee tot toenemende onreg en dispariteit. Hierdie toestande sal onstabiliteit in gemeenskappe en lande meebring, wat mense sal noop om te migreer na meer stabiele omgewings of lande. Hierdie bewegings sal weer in laasgenoemde lande aanleiding gee tot onstabiliteit en spanning (Goudzwaard, 1997:40-41).

Dispersie het reeds in Afrika tot groot gapings tussen ryk en arm gelei (Van der Walt, 1997:124 e.v.). 'n Klein persentasie Afrikane leef in baie groot weelde, terwyl die massas rondom hulle van die honger sterf. Hulpprojekte aan hierdie armes is niks anders nie as krummels van die tafels van die rykes af. Hierdie armoede lei tot die ontmensliking van duisende Afrikane. Dispersie in die verlede het alreeds ook gelei tot 'n gaping tussen die ryk lande van die noordelike halfrond en die armes van die suidelike halfrond, soos bewys tydens die Europese Unie-Afrikagesprek in Kaïro aan die begin van April 2000. 
J.L. van der Walt

Dispersie hou ook verband met die beskikbaarheid van werksgeleenthede. Die alreeds stygende kwalifikasiespiraal loop reeds op toenemende werkloosheid uit. Die armes raak armer omdat hulle nie werk nie, en ook weens die afskaling van hulpprojekte. Kerke en ander instansies sukkel toenemend om armes te hulp te kom, en kan nie meer op staatsondersteuning reken nie. Die skaarsheid van werk en die stygende kwalifikasiespiraal dwing mense selfs uit die middelklas uit en maak hulle deel van die arm klasse. Jongmense kan nie meer die lewenstandaarde van hulle ouers handhaaf nie, en moet leer om meer beskeie te leef (Sine, 1997:33, 35)

Hoewel 'n mens ook hier sou kon redeneer dat die al groter wordende gaping tussen ryk en arm onvermydelik en onontwykbaar is, is hier tog ook ander oorwegings ter sprake. Die rekkende gaping tussen ryk en arm is 'n funksie van die "dispersie"-tendens, en van 'n verkeerde siening van God se goedheid en oorvloedige gawes. Die antwoord is dus nie hand-outs aan die armes nie, maar om hulle te "bemagtig" (op te voed; toe te rus) om te kan deel in die oorvloedigheid van God. Die manier waarop ' $n$ mens daarin deel is deur 'n beroep te volg wat enersyds die beoefenaar daarvan self bevredig en ook die nodige materiële vergoeding kan voorsien (Ps. 90:17; Ps. 127:1-2; Jer. 22:3;4; 1 Kor. 10: 31; Kol. 3:17 2; Tess. 3:10) sodat ook die behoeftiges bemagtig/ opgevoed kan word

\subsection{Ontkerstening, kerkloosheid en kerklosheid}

Die kleiner wordende wêreld is ook besig om ten aansien van godsdiens en lewensbeskouing supermark- en karnavalagtig te word (Walsh, 1997: 17-18). Mense verlaat die hoofstroomkerke, skaar hulle by ander godsdienste of bedink 'n eie godsdiens. Dit het 'n tyd geword van godsdienstige promiskuïteit. Hoewel daar allerlei nuwe godsdienste en godsdienstige bewegings gekom het, is die godsdiens en die geloof nie meer dominant in die mens se bestaan en in die samelewing nie. Soos reeds aangedui, het die wetenskap en die tegnologie met die verengde rasionaliteit daaragter, in die plek daarvan gekom. Die mens van die laat twintigste eeu en van die vroeë 21 ste eeu het egter ook reeds tot die ontnugterende ontdekking gekom dat hierdie dinge nie in staat is om aan hom of haar ankers, rigting, leiding, en ordening te bied nie. Om hierdie rede, sê Dekker (1992:67) treffend, "horen we niet alleen spreken over een crisis in de religiositeit, maar ook over een crisis in de seculariteit".

Die (postmoderne) tyd waarin ons leef, word gekenmerk deur ankerloosheid en morele onstabiliteit. De Knijff (1992) praat van "een stuurloze wereld". Norme word beskou as blote menslike maaksels, en daar is 'n neiging tot relativisme (Walsh, 1997:11-13). Die agteruitgang in die 
Opvoeding vir die vroeg-21ste eeu: 'n Chnistelik-opvoedkundige perspektief

Christelike tradisie het ook gelei tot agteruitgang in 'n Christelike siening van kultuur (Tennekes, 1992; Vogelaar \& Bregman, 1984).

Die skepsis van die tyd word onder meer bespeur in die houding van jongmense wat die antwoorde van die ouer geslag en die "groot verhale van voorheen" as 'n spul leuens en bedrog afmaak. Die gewaande vooruitgangsgeloof van die kapitalisme - en sedert die val van die Berlynse muur ook van die kommunisme - is voorbeelde van sulke "groot verhale" (Walsh, 1997:14)

Oor die tema van die sekulêre humanisme is daar reeds boekdele geskryf. Hart (1968) het lank gelede al byvoorbeeld verwys na "die koninkryk van die mens", in teenstelling met die koninkryk van God. Die tendens om die koninkryk van die mens te bevorder lê aan die wortel van al die mensgerigte en -gesentreerde tendense van ons huidige tyd en van die voorsienbare toekoms. As die mens nie terugkeer tot God en sy diens nie, as hy nie terugkeer tot 'n sinvolle religieuse verhouding met sy Skepper nie, en Jesus Christus nie beskou as sy verlosser en as die herskeppingsmiddelaar van hierdie gebroke skepping nie (Dooyeweerd, $1969 \mathrm{l}: 173$ e.v.), dan is alles wat so 'n mens doen op losse skroewe, en is die neiging om die pad byster te raak, onvermydelik. Die oplossing vir die probleem van die sekulêre humanisme, so het baie Christendenkers deur die eeue heen al met geloofsoortuiging gesê, is 'n onverwylde religieuse terugkeer tot God en sy gebod (Schoeman, 1975:23 e.v.).

\subsection{Die neiging tot post-rasionaiiteit in die hedendaagse kultuur}

Die huidige kultuur het veelal reeds 'n post-rasionele kultuur geword: alles word - ondanks dit wat van die wetenskap en die tegnologie in 3.5 hierbo gesê is - nie noodwendig rasioneel of wetenskaplik benader of beoordeel nie. Daar het reeds 'n herbedinking van die kenproses plaasgevind. Die kenner staan nie noodwendig meer los van die kenbare, die kenproses en die kenresultaat nie, maar vorm veelal deel daarvan (Walsh, 1997:15).

Net soos wat 'n oordrewe nadruk op die rede en sy vermoëns nie aanvaarbaar is nie, is dit ook nie aanvaarbaar as die huidige kulturele tydsgewrig post-rasioneel of selfs irrasioneel (in filosofiese sin) raak nie (vgl. byvoorbeeld Vollenhoven, 1956:39 e.v.; Singer, 1979). Hierdie tendens dui op onewewigtigheid, aangesien die redelike vermoë of funksie van die mens maar een van vele van sy of haar vermoëns is. 'n Onewewigtige pendulum-agtige "uitswaai" van die redefunksie van die mens na die een of die ander kant is enersyds 'n aanduiding van onewewigtigheid, maar kan ook 'n aanduiding wees van 'n miskenning 
van die ander funksies van menswees, soos liefde vir God en die naaste, die sin vir billikheid en regverdigheid, of ewewigtige sosiale verkeer.

\subsection{Gefragmenteerde kits- en weggooikultuur}

Die (postmoderne) lewe neig om gefragmenteerd te wees, heterogeen, vol verskille en kontraste, en daar is ' $n$ opvallende bevraagtekening en selfs verwerping van eenheids- en heelheidsopvattings. Hierdie gefragmenteerde kultuur neem dikwels die vorm aan van 'n kits- en weggooikultuur; dit is 'n kultuur wat toenemend onwerklik raak, sonder enige substansie, virtueel van aard (Walsh, 1997:18-20). Hierdie kits- en weggooimentaliteit is ook nie slegs beperk tot materiële goedere nie, maar sluit ook fasette van spiritualiteit in, soos godsdiens, lewensbeskouing, waardes en norme (Goudzwaard, 1997:40).

Hierdie tendens is kenmerkend van kulturele vervlakking. Die mens van die laat-20ste en vroeg-21ste eeue bevind hom tipies in ' $n$ oppervlakkige supermark- of inkopiesentrumkultuur, waar die aanbod onbeperk is en waarin die mens tot blote verbruiker gedegradeer word. Hierdie verbruiken weggooikultuur vind selfs uitdrukking in sake wat volgens die Woord van God veronderstel is om duursaam te wees, soos die huwelik, die gesinslewe, menslike verhoudinge, kerklike verbintenis, vriendskappe, en vele meer. Die kern van die probleem skyn weer eens te lê in 'n oppervlakkige beskouing van kultuurbeoefening, 'n verkeerde opvatting van wat die kultuurmandaat werklik behels. Hoewel dit moeilik gaan wees om hierdie tendens te bestry, rus daar ' $n$ dure verantwoordelikheid op Christenopvoeders om die mense van die toekoms toe te rus om die gevare van hierdie tendens raak te sien. Hulle moet begelei en toegerus word om ' $n$ waardestelsel te bou waarin die regte waardes aan die regte dinge toegeken word.

\subsection{Mensgesentreerdheid}

Daar is in die hedendaagse tydsgewrig ' $n$ opvallende tendens tot sekulêre humanisme, wat onder meer ook uitdrukking vind in vorme van besorgdheid oor "die ander". Dit is vir Walsh (1997:22) opvallend dat hierdie tendens nie slegs "daar buite" by ander mense bespeurbaar is nie, maar ook "hier binne" by elke mens self. Hierdie neiging gaan dikwels gepaard met die privatisering van norme en waardes, waardeur waardes en norme sake van persoonlike voorkeur en gevoel word (Tennekes, 1992:53). Tennekes (1992:55) betreur dit dat die postmoderne tyd waarin die hedendaagse mens leef, gekenmerk word deur relativisme en individualisme, en dat daar nie meer in die samelewing konsensus is oor sentrale waardes nie. Ten spyte van hierdie nuwe 
Opvoeding vir die vroeg-21ste eeu: 'n Christelik-opvoedkundige perspektief

aandag vir die mens en sy behoeftes, is daar egter ook weer 'n duidelik sigbare tekort aan liefdevolle medemenslikheid (Goudzwaard, 1997:46).

Mensgesentreerdheid is ' $n$ funksie van die humanistiese sekularisme van die tyd (vgl. 3.10 hierbo). Die mens, wat God as die religieuse sentrum of fokus van sy lewe laat vaar het, het die ingebore neiging om religieus op iets anders te fokus of in iets te sentreer. In baie gevalle fokus die mens op homself of op die voordeel van die mensdom in die algemeen (Fowler, 1987:1-9). Die Skrif leer egter dat geen self- of medemenslike liefde moontlik is sonder die rigtinggewende liefde vir God nie. Die mens wat die self en die naaste waarlik en ewewigtig lief wil hê, moet op God gefokus wees (I Joh. 3:17).

\section{Enkele evaluerende opmerkings en aanbevelings}

Voorgaande toekomsscenario is uiteraard onvolledig, maar dit dien 'n belangrike doel: dit beeld iets van die toekoms uit waarmee die Christenopvoeder en -opvoedkundige rekening sal moet hou. Hierdie "rekening hou" veronderstel nie reaktiewe optrede nie, dog wel proaktiewe posisionering vir die beste wyse waarop opvoeding en onderwys behoort te geskied ten einde volle reg te laat geskied aan die beproefde doelstellings van die Christelike opvoeding, soos in die Skrif verwoord in Deuteronomium 6:6-9 en 2 Timoteus 3:14-16.

By al die waardering wat 'n mens kan hê vir die Suid-Afrikaanse onderwysowerhede se prioriteite soos geformuleer in die "Batho Tele"en die "Tirisano"-programme, kan 'n mens nie anders nie as om tot die gevolgtrekking te geraak dat daar in die ontwerp van hierdie programme nie voldoende kennis geneem is van die ingrypende wêreldwye veranderinge van die laaste paar dekades nie. Dit wil voorkom asof die vyf prioriteite uitgespel in die "Tirisano"-projek taamlik sterk gefokus is op die plaaslike problematiek van Suid-Afrika, ten spyte van die voorneme om die projek binne die konteks van globale, en veral Westerse, kulturele veranderinge te benader, soos in die vooruitsig gestel in die AfrikaRenaissance-veldtog. Van die sosiokulturele veranderinge in die breë omwêreld wat in afdelings 2 en 3 hierbo geskets is, word nie veel bemerk nie. Die feit dat dit so is, kan waarskynlik toegeskryf word aan die feit dat die onderwysowerhede in Suid-Afrika nog besig is met ' $n$ regstellingsproses na afloop van die apartheidsbedeling, en die luukse van wyer kyk dus nog nie bekostig kan word nie.

Hoewel daar begrip kan wees vir hierdie (hopelik voorlopige) fokus op die plaaslike Suid-Afrikaanse onderwystoestande, is dit belangrik vir die opvoeder en opvoedkundige om ook vorentoe en breër te kyk. Indien dit 
nie gebeur nie, kan Suid-Afrikaanse opvoeders en opvoedkundiges hulle iewers in die toekoms die volgende verwyt op die hals haal:

I believe much of what we do in education is unconsciously designed to prepare the young to live in the world we grew up in instead of the third millennium. I have seen little in either public or private education that is intentionally designed to enable students to anticipate and creatively respond to the challenges of tomorrow's world (Sine, 1997:25).

Dit is veral vir die Christenopvoeder belangrik om die opvoedeling nie slegs te vorm en toe te rus vir die wêreld en die lewe soos dit tans is nie, maar om die wêreld te verander tot wat dit kan wees in en deur die krag van Jesus Christus.

Die tendense in afdelings 2 en 3 hierbo bespreek vra dus van die Christenopvoeder en -opvoedkundige verantwoorde, Skrifgefundeerde optrede.

\section{Samevattend}

'n Mens sou al voorgaande Skrifgefundeerde riglyne met die volgende paar woorde kon saamvat: in plaas van die hedendaagse sekulêrhumanistiese neiging tot die verlaat van God en sy gebod moet daar weer teruggekeer word tot wat God sy kinders beveel het om te doen ten opsigte van hulle liefde vir Hom, hulle liefde en diens aan hulle naaste, hulle verantwoordelike beheersing van die skepping wat $\mathrm{Hy}$ aan hulle toevertrou het, en tot die opvoeding en toerusting van die kinders wat $\mathrm{Hy}$ uit genade en liefde aan hulle gegee het. As hierdie besef behoorlik posvat, sal toekomsscenario's uiteraard heeltemal anders daar uitsien, en sal projekte soos "Tirisano" baie omvattender en tegelyk gerig op die diens van die God van die Bybel kan wees. Of dit haalbaar sal wees in 'n multigodsdienstige en -kulturele land soos Suid-Afrika is egter 'n ander vraag.

\section{Bibliografie}

ANON. 2000. Die "Batho Tele" en "Tirisano" Programme. Mondstuk, 29(317):1-2, Feb.

ASMAL, K. 1999. Asmal launches massive education mobilisation. Media Release. Pretoria : Ministry of Education

ASMAL, K. 2000. Message from the Minister of Education. Implementation Plan for Tirisano. January 2000 - December 2004. Pretoria : Department of Education

ASMAL, K. 2000b. Interview with Philippa Garson: Vision for a new era. The Teacher, 5(4):4, Jan

BAER, R.A. 1987. American public education and the myth of value neutrality (In Neuhaus, R.J. Democracy and the renewal of public education. Grand Rapids : Eerdmans. p. 1-24.) 
Opvoeding vir die vroeg-21ste eeu: 'n Christelik-opvoedkundige perspektief

BYBEL. 1993. Die Bybel in Praktyk. Onder redaksie van Vosloo, W. \& Van Rensburg, $F$. Vereeniging : CUM

DEKKER, G. 1992. De rol van de Christelijke traditie in de Nederlandse samenleving. (In De Knijff, H.W., Dekker, G \& Tennekes, J. Christelijke waarden in een geseculariseerde cultuur. Amsterdam : VU-Uitgeverij. p 63-86.)

DE KNIJFF, H.W. 1992. De Christelijke traditie in een door wetenschap bepaalde wereld (In De Knijff, H.W., Dekker, G \& Tennekes, J. Christelijke waarden in een geseculariseerde cultuur Amsterdam : VU-Uitgeverij. p. 5-34.)

DEPARTMENT OF EDUCATION. 1997. Call for comments on the draft statement on the National Curriculum for grades 1-9. Government Gazette. Vol. 384 (18051) Pretoria. 6 June.

DOOYEWEERD, H. 1969. A new critique of theoretical thought Vol. I Phillipsburg: The Presbyterian and Reformed Publishing Company.

DOOYEWEERD, H 1979 Roots of Western culture. Pagan, secular and Christian options Toronto: Wedge

ENGELBRECHT, S.W.H. \& NIEUWENHUIS, F.J 1988 Onderwysstrategieë vir die toekoms. (In Marais, H.C., red. Suid-Afrika: perspektiewe op die toekoms. Durban : Owen Burgess. p 163-188.)

FOWLER, S. 1987. Christian educational distinctives. Potchefstroom : PU vir CHO. (Instituut vir Reformatoriese Studie.)

GOUDZWAARD, B. 1997. Towards a future of care. (In Lambert, I. \& Mitchell, S The crumbling walls of certainty. Sydney : Centre for the Study of Australian Christianity. p. 40-49.)

HART, H 1968. The challenge of our age Toronto: The Association for the Advancement of Christian Sudies.

MBEKI, T 1999a Statement by President Thabo Mbeki to the Afrikanerbond. Pretoria. 27 July.

MBEKI, T. 1999b. Address by President Thabo Mbeki to the SADC local government conference. Johannesburg 30 July

MSELEKU, T. 2000. Foreword by the Director-General. Implementation plan for Tirisano January 2000 - December 2004. Pretoria : Department of Education

RUSHDOONY, R.J 1969. The Biblical philosophy of history. Phillipsburg : The Presbyterian and Reformed Publishing Company.

SAOU 2000 Kommentaar: Hersieningskomitee van prof. Asmal (Minister van Onderwys). Nuus in die Branding, 9/2000.

SCHOEMAN, P.G. 1975. Grondslae en implikasies van 'n Christelike opvoedingsfilosofie Bloemfontein : SACUM.

SINE, T 1997. Shifting education into the future tense: Raising our hopes. (In Lambert, I. \& Mitchell, S. The crumbling walls of certainty. Sydney: Centre for the Study of Australian Christianity. p. 25-39.)

SINGER, C.G. 1979. From rationalism to irrationality. Phillipsburg : Reformed and Presbyterian Publishing Company

SLEETER, C.E. \& GRANT C A. 1994. Making choices for multicultural education. New York : Macmillan.

SUNTER, C. 1996. The high road: Where are we now? Tafelberg : Human \& Rousseau.

TENNEKES, J 1992. Christenen en cultuurvorming. (In De Knijf, H.W., Dekker, G \& Tennekes, J. Christelijke waarden in een geseculariseerde cultuur. Amsterdam VU-Uitgeverij p. 35-62.)

VOLLENHOVEN, D.H.T. 1956. Kort overzicht van de geschiedenis der Wijsbegeerte. Amsterdam : Theja. 
VAN DER WALT, B.J 1997. Afrosentries of Eurosentries? Ons roeping in 'n multikulturele Suid-Afrika. Potchefstroom : PU vir $\mathrm{CHO}$. (Instituut vir Reformatoriese Studie.)

VOGELAAR, D \& BREGMAN, C. 1984. School, maatschappij en cultuur in Bijbels licht. Hendrik Ido Ambacht : Begeleidingscentrum Gereformeerd Schoolonderwijs.

WALSH, B.J. 1997. Education in precarious times: Postmodernity and a Christian world view. (In Lambert, I. \& Mitchell, S. The crumbling walls of certainty Sydney : Centre for the Study of Australian Christianity. p. 8-24.)

WRAGG, T. 1984. Education for the twenty first century. (In Harber, C, Meighan, R. \& Roberts, B. Alternative educational futures. London: Holt, Reinhart \& Winston. p. 1-12.)

\section{Kernbegrippe:}

21ste eeu

Christelike perspektief

onderwys

opvoeding

toekomsstudies

\section{Key concepts:}

Christian perspective

education

future studies

twenty first century 